\title{
IMPROVING CONCEPT MAPPING SKILL THROUGH INQUIRY INSTRUCTION
}

\author{
S. Gumilar*1, W. Setiawan² \\ 1Department of Elementary School Education, \\ Sekolah Tinggi Keguruan dan IImu Pendidikan Sebelas April, Indonesia \\ 2Department of Computer Science Education \\ Indonesia University of Education, Indonesia
}

Received: 20 February 2016. Accepted: 1 May 2016. Published: July 2016

\begin{abstract}
The purpose of this research was to analyze implementation of inquiry instruction for improving concept mapping skill. The subject of the research was student on grade 10 in islamic senior high school in subang district. Method of research used was quasy experiment with matching control group pretest-posttest design. Instruments used in this research were test and concept map about electricity. The treatment of experiment group was the combination of virtual-real experiment and virtual experiment, while control group was only real experiment method. The result of analyzing data showed that the average of normalized gain $\langle\mathrm{g}\rangle$ was in low criteria. Significant test of three averages normalized gain using analysis of varians (anova) showed that virtual-real experiment method was more significant in improving mapping concept skill than those virtual experiment and real experiment only.
\end{abstract}

\begin{abstract}
ABSTRAK
Penelitian ini bertujuan untuk menganalisis penerapan pembelajaran inkuiri dalam meningkatkan ketrampilan membuat peta konsep. Subjek penelitian yang digunakan adalah siswa kelas X pada salah satu Sekolah Menengah Atas Islam Terpadu di Kabupaten Subang. Metode penelitian yang digunakan adalah Quasy experiment dengan desain penelitian matching control group pretest-posttest. Instrumen yang digunakan dalam penelitian ini adalah tes dan peta konsep mengenai kelistrikan. Kelas eksperimen dalam penelitian ini memperoleh perlakuan kombinasi metode eksperimen nyata-virtual dan virtual saja, sedangkan kelas kontrol memperoleh perlakuan metode eksperimen nyata saja. Hasil perhitungan rataan gain $\langle\mathrm{g}\rangle$ yang ternormalisasi menunjukkan bahwa peningkatan kemampuan membuat peta konsep berada pada kriteria rendah. Hasil uji signifikansi ketiga rataan $<g>$ menggunakan analysis of varians (ANOVA) menunjukkan bahwa metode eksperimen nyata-virtual lebih signifikan dalam meningkatkan keterampilan membuat peta konsep dibandingkan dengan metode eksperimen virtual saja dan nyata saja.
\end{abstract}

@ 2016 Jurusan Fisika FMIPA UNNES Semarang

Keywords: inquiry; mapping concept

\section{INTRODUCTION}

The concept of electricity has special characteristic that it has abstract concept. This is similar to the stating of phrase Choi and Chang (2004) that the subject has an abstract concept such as current, potential difference, and energy-burning electricity. Abstractness this concept also makes a lot of students have difficulty understanding (Mustafa, Baser \& Son-

*Correspondence Address:

Jl. Anggrek Situ No.19 Sumedang

E-mail: ayrusgumilar@gmail.com er, 2011). Many students do not understand very well about the concept of direct current electric circuits. Difficulties often encountered such an understanding of the law of conservation of charges, relationship current with potential difference, and the amount of the potential difference in the circuit series, parallel, and mixed (Engelhardt \& Beichner, 2004)

Abstract characteristics of the subject require an appropriate learning for its teaching process. Of course, it can be done by providing a meaningful learning to the students so 
to grow a good understanding of the concepts learned.

One of the indicators to see poor understanding of students can be seen when a lot of students have not been able to figure the concepts that have been studied. Weak illustration of this concept is certainly as a result of the meaningfulness of the learning has not been reached. One major indicator of the significance of learning can be seen when students are able to create meaningful relationships of concepts. This meaningful relationship of concepts can be seen in the form of a mapping concept showing the concepts learned. Novak, Coffey \& Carnot. (2003) states that in any meaningful learning process students are able to relate the concept with other concepts. One of the benchmarks used to determine meaningfull learning process experienced by students that it can be seen from the ability to create a mapping concept. Through mapping concept, the significance of the concept of the student will be shown in several aspects such as crosslink, hierarchy, propositions, and examples are presented. In the fact, during this time, it is not yet fully trained to the students. Whereas with the ability to create mapping concept, students will be able to pack the structure overview from the general concepts to specific based on what they have learned.

One of learning methods that it is emphasized in meaningfull learning is experiment method. Experiment method is a way to service subject of learning where students are active experiencing and proving themselves about what they have learned. According to form of experiment, it can be divided by experiment of idea, computer (virtual), and real experiment (Druxes, 1986). The form of experiment implemented in learning is virtual and real experiment.

The real experiment has unique advantage such as to connect student really and actively to real object (Fiesel \& Rossa, 2005). Bara (Zacharia, 2011) states that real experiment was a base form from learning procces and was remember counciosly. Zacharia (2011) also states that via real experiment student can gain their experience through many investigations, use scientific tool truly, collect, write, and analyze data really. More than that, real experiment can give opportunity in error measurement rised naturally from experiment that it has done.

Bisides having advantage, there are some limitations when real experiments met- hod is applicated in learning such as requires a longer time, have little mobility and range, limited in place and time, need high cost for buying equipment of experiments, as well as more expensive the cost of maintenance and procurement (Saepuzaman, 2011).

The development of technology contributes to field of education. Several studies were done through the virtual laboratory experiments. This provides a positive impact on learning as it builds skills, attitudes, and understanding of the concept. According to Triona and Klahr (Zacharia, 2011), there are many advantages in using of virtual experiment in learning that it is easier, safer, cost efficient, minimizing uncertainty, minimize the space and time, and flexible and fast enough to display the data more accurately.

Some other advantages of virtual experiments were obtained from several studies such as provide the skills to make eficient the time and make more simple object model that it is easy to learn, provide rich information and a diverse picture in the form of verbal, numeric, image, concept and graphs of the environment, engage students in changing the variables that it is not real, provide feedback quickly about the uncertainty in the students and provide an opportunity to repeat the same experiment as soon as possible, facilitate learning by focusing attention students more directly the phenomenon, involves students to visualize objects and process normally beyond perception and simplify it, engage the students to perform experiments more widely, quickly and easily and provide experience with many examples, give students experience on what real experiments are difficult or expensive to do (Zacharia, 2011).

Table 1. Involving instruction based inquiry with combination virtual-real experiment to aspect of mapping concept

\begin{tabular}{|c|c|}
\hline $\begin{array}{l}\text { Instruction based } \\
\text { inquiry }\end{array}$ & $\begin{array}{l}\text { Aspect of mapping } \\
\text { concept }\end{array}$ \\
\hline Problem & Giving example \\
\hline $\begin{array}{l}\text { Formulating hypoth- } \\
\text { esis }\end{array}$ & Constructing propotition \\
\hline $\begin{array}{l}\text { Collecting Data } \\
\text { (Real experiment } \\
\text { method) }\end{array}$ & Constructing proposition \\
\hline Analyzing Data & $\begin{array}{l}\text { Training proposition } \\
\text { Training crosslink }\end{array}$ \\
\hline $\begin{array}{l}\text { Making conclusion } \\
\text { (Virtual experiment as } \\
\text { reinforcement ) }\end{array}$ & $\begin{array}{l}\text { Training hierarchy } \\
\text { Training example }\end{array}$ \\
\hline
\end{tabular}


Based on the advantages of both the experimental method in above, they are appeared to provide meaningful learning experiences for students during the learning process. Moreover, the learning process is applied based inquiry learning by combining two experimental methods. Through the learning students will find a number of concepts through a series of experiments were performed, either real or abstract concept. Ideally, in the end the students will be able to describe the concept as a whole through the relationship of the concept with other concepts expressed in the mapping concept skill.

Table 1 shows how the frame of the phases of inquiry instruction with a combination of real-virtual experiment method trains aspects of mapping concept. The final goal of course achieve meaningfulness of student learning both for real or abstract concept illustrated by an increasing in the ability of students mapping concept.

\section{METHOD}

This research used true experiment method with matching control group pretestposttest design (Fraenkel \& Wallen, 2007). The design of research was chosen because of its suitability for testing effect of an independent variable treatment research that it is real-virtual experiment based inquiry instruction on the dependent variable that it is the ability to make a mapping concept. In this research, a mapping concept is used as a skill tested and instrument test.

Table 2. Scheme of Matching Control Group Pretest-Posttest Design

\begin{tabular}{lccc}
\hline Group & Pretest & Treatment & Posttest \\
\hline Experiment I & $\mathrm{T}_{1}$ & VRE & $\mathrm{T}_{2}$ \\
Experiment II & $\mathrm{T}_{1}$ & $\mathrm{VE}$ & $\mathrm{T}_{2}$ \\
Control & $\mathrm{T}_{1}$ & $\mathrm{RE}$ & $\mathrm{T}_{2}$ \\
\hline
\end{tabular}

Note: virtual-real experiment (VRE), real experiment (RE), and virtual experiment (VE).

The population of this research was students at tenth grade of Islamic senior high school. There were four total groups in population. While the sample of the research include three group of male and female, group X-1 (male), X-2 (male), and X-2 (female). Each group consists of 27 students, so the total sample in this study was 81 students of seni- or high school. Technique of sampling that it is used was purposive sampling of the population that it was taken based on purpose of researcher.

The instrument developed in this research was a standard mapping concept created by the researcher. Tests ability of student to create a mapping concept was obtained from project mapping concept students. Assessment of the project mapping concept of students was assessed with a standard mapping concept created by the researcher. Standard mapping concept made reference to the asessment of mapping concept was developed by Novak and Gowin (1984) which it includes the hierarchy, crosslink, propositions, and examples. The rating of quality of mapping concept according to Novak, Coffey \& Carnot (2003) can be seen as shown in Table 3.

Table 3. Quality for criteria of assessing mapping concept by Novak

\begin{tabular}{ll}
\hline Aspect & Quality of value \\
\hline Hierarchy & 5 for valid hierarchy \\
Crosslink & 10 for valid crosslink \\
Proposition & 1 for valid proposition \\
Example & 1 for valid example \\
\hline
\end{tabular}

To determine the significance of increasing the ability to make a mapping concept was done by some data analysis techniques such as Kolomogorov Smirnov test (KS) and Levene, normalized gain $\langle\mathrm{g}\rangle$, analysis of variance (ANOVA) or Kruskal Whallis and Tukey's HSD or Average Rank.

\section{RESULT AND DISCUSSION}

The results obtained include the enhancement of ability to make a mapping concept of students in general and the enhancement in every aspect of the mapping concept.

\section{Enhancement of mapping concept skill}

A general description of the enhancement in the ability to make a mapping concept is done by calculating the normalized gain $<g>$. Table 4 shows that the greatest value of the normalized gain $\langle\mathrm{g}\rangle$ of VRE group is 0.21 . Then the data for gain of VE and RE are 0.17 and 0.12 . Although each of average $\langle\mathrm{g}\rangle$ is different for each other, all of them are in the low category according to Hake criteria (1998). 
Table 4. Enhancement of mapping concept skil for all criteria

\begin{tabular}{lccc}
\hline Group & $\mathrm{N}$ & $\langle\mathrm{g}\rangle$ & Category \\
\hline VRE & 27 & 0.21 & Low \\
VE & 27 & 0.17 & Low \\
RE & 27 & 0.12 & Low \\
\hline
\end{tabular}

Testing the significance of the enhancement in mapping concept skill in this research is done using Kruskal Wallis test. It is because the data are not normally distributed. The result of significance test looks like in table 5.

Table 5. Result of significant Kruskal Wallis (KW) test of enhancement of mapping concept skill

\begin{tabular}{lcccc}
\hline Group & $\mathrm{N}$ & $<\mathrm{g}>$ & $\begin{array}{c}\text { Ave } \\
\text { Rank }\end{array}$ & $\mathrm{KW} \mathrm{H}(\mathrm{p})$ \\
\hline VRE & 27 & 0,21 & 58,0 & \\
VE & 27 & 0,17 & 47,8 & 29,51 \\
RE & 27 & 0,12 & 23,0 & $(0,00)$ \\
Total & 81 & & 41,0 & \\
\hline
\end{tabular}

Based on calculations of Kruskal Wallis test shows the value $\mathrm{H}=29.51(\mathrm{p}<0.05)$. This shows that the average $<g>$ for each group different from another. To see the most significant value normalized gain $\langle g\rangle$ can be seen from the value ave rank. The value of ave rank VRE (58.0) is greater than the total value ave rank (41.0), this indicates that $\langle g>$ VRE significantly different compared to the others. In other words, it also shows that the combination of virtual-real experiment method (VRE) based inquiry instruction can improve significantly the ability to create a mapping concept of physics than virtual experiment methods (VE) and the real experiment (RE).

The findings of the result of study were not surprising because the combination of virtual-real experiment give more experience to the students. Repetition of inquiry-based virtual experiment will reinforce what has been obtained from real experiments based inquiry. This is also macth with the findings of previous studies showing that instruction based inquiry with virtual-real experiments (VRE) provide a more significant enhancement of understanding concepts and mastery of concepts (Zacharia 2010; Saepuzaman 2011). Some of the factors caused VRE provides a significant enhancement in the ability to make a mapping concept than the other is the value of experien- tial learning, repetition of meaningful activities, learning activities that match the characteristics of the subject matter, and accommodating students' cognitive level.

Basically, VRE learning bridges the value of the learning experience more meaningful in enhancing the ability to make a mapping concept than VE and RE learning. It was caused in a real experiment of VRE learning presenting early framework related direct experience of students regarding the investigation of real objects. This is consistent with the expression Fiesel and Rossa (2005) which states that the real experiment presenting the initial experience for students who are active and tangible to work with objects. Initial framework formed by the real experience will be combined with the match modeling that appropiate to real experience through the activity of virtual experiments. Finally, students had value of meaningful learning experience comprehensively in the formation of the basic framework of knowledge.

Meanwhile, factor of the repetition of inquiry activities presented in VRE was a cause of increasing the ability to make a mapping concept more significant than any other study (VE and RE). Through real experiment method based inquiry instruction, learning experience of student will last longer. As confirmed by Bara (Zacharia, 2011) that the real experiment is a conscious process of remembering. By doing virtual experiments based inquiry through the investigation of the same phenomenon make replanting process of memory through meaningful experiences that they were presented. This will effect to enhance in the mapping concept skill that it was significantly different compared from VE and RE learning that they present only one phenomenon investigated.

In addition to the two factors in above, another factor why VRE is more significant increase the mapping concept skill because of presenting learning activities that it is match to the subject matter. The subject matter in the electrical circuit has abstract concepts (Choi and Chang, 2004), and it is difficult to understand (Mustafa, Baser \& Soner, 2011) presented through real learning framework and modeling. Real experiment based inquiry instruction gives a real picture of the conditions studied through investigation of the senses such as shape, texture, and characteristics of object. Then modeling gives new ideas how an abstract concept is modeled through virtual experiments based inquiry intruction. Obviously this gives a new idea about the clarity of the 
abstract concepts to become more apparent (Zacharia, 2011).

Another factor influencing the VRE based inquiry learning in facilitating enhancement of the ability to make a mapping concept more significant is the nature of learning that it can accommodate students' cognitive level. Giving real experiment to students early, teaching students investigates from simple to concrete phenomena. Then step to abstract fenenomena perceived more difficult, provision of virtual experiment makes the phenomenon seem more visible so as to accommodate the students' cognitive level to understand more complex concepts (Zacharia, 2011).

The above results indicate that enhancement of ability to make a mapping concept of the overall concept for all classes increased, but it was in low category. One reason why it is happened because of lack information to dig knowledge from student uses test of mapping concept. Although the results of statistical tests showed that the average mapping concept of VRE significantly different compared to the others. The low value of the increased ability to make a mapping concept because students are not given stimulus can dig existing concepts in cognitive structure during the tests the ability to make a mapping concept done.

Although many studies use mapping concept as a tool to measure instruction based inquiry (Stodart 2000; Himangsu, 2012). It seems meaningfulness of learning through an indicator measuring the ability to make a mapping concept should be given the same stimulus in the form of questions such tests in general. Thus, the mapping concept skill students will be explored in expressing what is in the cognitive structure students. This differs from the measurement of understanding of the concept in general, providing information in early. In that case, students are stimulated to emerge the structure of knowledge but it does not apply to the ability to make a mapping concept when it is only given guidance to pour what is in the cognitive structure. It clearly appears that the meaningfulness of learning which is illustrated by an enhancement in the ability to make a mapping concept is lower than the meaningfulness of learning as measured by a common test. This does not mean that VRE based inquiry instruction or the other (VE and RE) does not facilitate the meaningfulness of learning which is reflected through the ability to create mapping concept.

Other factors associated with a lower enhancement in the ability to make a mapping concept are the difficulty to emerge or explore the cognitive structure of students that are embedded in the memory of students. Basically the students have experienced some kind of meaningful learning through VRE, VE, and RE based instruction. Digging the understanding of the cognitive structure of the student would be very difficult without the stimulus from the outside. This is as Gelder (2005) mentions that the memory needed to emerge up the information associated with the memory.

\section{Enhancement of mapping concept skill per aspect}

Results of processing data on the average normalized gain $\langle g\rangle$ for each aspect can be seen in Table 5.

Table 5. Normalized gain of mapping concept skill per aspect of mapping concept

\begin{tabular}{lccccc}
\hline \multirow{2}{*}{ Group } & \multirow{2}{*}{$<\mathrm{g}>$} & \multicolumn{4}{c}{$<\mathrm{g}>$ per aspect } \\
\cline { 3 - 6 } & & $\mathrm{Hi}$ & $\mathrm{Cr}$ & $\mathrm{Pr}$ & $\mathrm{Ex}$ \\
\hline VRE & 0,21 & 0,56 & 0,00 & 0,32 & 0,00 \\
VE & 0,17 & 0,52 & 0,00 & 0,22 & 0,00 \\
RE & 0,12 & 0,49 & 0,00 & 0,19 & 0,01 \\
\hline
\end{tabular}

Note: Hierarchy (Hi), Crosslink (Cr), Proposition $(\operatorname{Pr})$, dan Example (Ex)

Based on the data, the all groups have normalized gain in low category. The normalized gain of hierarchy aspect for all groups was in medium in the Hake's category (1999). The group of VRE had the biggest average value $(<g>=0.56)$. While aspects of the crosslink $(<g>=0.00)$ for the all group are in a lower category, the same thing happened to aspects of the example $(<\mathrm{g}>=0.00$ and crosslink $<\mathrm{g}>=$ $0.01)$. For aspects of proposition, the group of VRE was in the medium category $(<g>=0.32)$ and other classes are in the low category. The above data shows that the the group of VRE provide a higher enhancemente in quantity compared to the other classes in the enhancement the ability to create mapping concept in aspects of hierarchy and propositions.

The result of processing data shows that enhancement of the ability to create a mapping concept for each instruction to be in the low category. The ability to create mapping concept can be analyzed based on aspects of forming a mapping concept such as hierarchy, crosslink, proposition, and example. In the aspect of hierarchy and propositions, VRE based inquiry 
instruction has normalized gain with medium quality and the highest compared with other aspects while the crosslink aspects and examples do not show any enhancement in the value of normalized gain for all classes.

Basically inquiry instruction (VRE, VE, and $\mathrm{RE}$ ) can facilitate the formation of hieraki aspect in the ability to make a mapping concept. This is caused the investigation of systematic inquiry (Gulo, 2002). Enhancement of the highest aspect hierarchy was indicated by VRE compared to other learning. Factors affecting it relates to the systematic investigation process repeated. In the process of VRE students acquire, analyze and conclude data. The process is one of examples how the investigation of particular concepts led to the conclusion that it was a general concept. In addition through real experiment based inquiry, the process is performed again by students through virtual experiments. This is what makes learning VRE better in improving aspects of the hierarchy than other.

While aspects of the proposition shows the different qualities between VRE compared with VE and RE. VRE has modest enhancement of quality while others have a lower quality of improvement. This occurs because the process of VRE based inquiry provide planting concept that they can accommodate the cognitive aspects of from the concrete to the abstract concept (Zacharia, 2011). In contrast to two aspects in above, aspects of crosslink and examples are not improving. One of the factors associated with it is focused the study on the investigation of the concept. By the time student works in the inquiry, the formation of propositions and systematic knowledge structure is formed through a number of stages of the learning activities. But the relationship bridge broader and far concept was not achieved optimally. So on this side, part of leap the linking process of the concept of creativity from a different domain is not reached. The leap of creativity is the basis for training crosslink (Novak, Coffey \& Carnot, 2003). On the other hand, focused on the efforts of the investigation of concepts ignore example aspects for concepts that are not investigated so that the impact on the optimalitation aspect of example in the ability to create mapping concept of students. In addition, no appearance of example aspects was because students can not pull the significance of any problems that are shown at the beginning of learning.

\section{CONCLUSION}

From the results of data processing and analysis can be concluded that improving the ability to make a mapping concept as one indicator of meaningful learning can be enhanced through the implementation of combination of virtual-real experiment based inquiry instruction.

Suggested for researchers in education field who want to use mapping concept as an evaluation tool to determine the meaningfulness of learning, students should be given directives in the form of questions that can stimulate the excavation of the concept.

\section{REFERENCES}

Choi, K. \& Chang, C. (2004). The Effects of Using the Electric Circuit Model in Science Education. Journal of the Korean Physical Society. 44,(6), 1341-1348.

Druxes, H. (1986). Kompendium Didaktik Fisika. Bandung: Remadja Karya.

Engelhardt, P. \& Beichner, R. (2004). Students understanding of direct current resistive electrical circuits. American Journal of Physics, 72(1), 98-115.

Feisel, L. D. \& Rosa, A. J. (2005). The role of the laboratory in undergraduate engineering education. Journal of Engineering Education. 94(1), 121-130.

Fraenkel, J. R. \& Wallen. (2007). How to Desain and Evaluate research in Education. New york: Mc Graw-Hill International Edition.

Gelder, V. (2005). Teaching critical thinking some lessons from cognitive science. Journal College teaching. 53(1), 41-48.

Gulo, W. (2002). Stategi Belajar Mengajar. Jakarta: PT Gramedia Widiaswara Indonesia.

Hake, R. R. (1998). Interactive-Engagement Versus Tradisional Methods : A Six-Thousand-Student Survey of Mechanics Tes Data For Introductory Physics Course. American Journal Physics. 66(1), 64-74.

Himangshu, S. (2012). Mapping conceptping in the teaching of physical science: assessment of real world applications of wave energy by pre-service teachers negotiating concept understanding. Proceding of the fifth international Conference on Mapping Conceptping.

Mustafa, B., \& Soner, D. (2011). The effectiveness of computer supported versus real laboratory inquiry learning environments on the understanding of direct current electricity among pre-service elementary school teachers. Eurasia Journal of Mathematics Science and Technology Education, 6(1), 47-61.

Novak, J. D, Coffey, J. W. \& Carnot, M. J. (2003). 
A Summary of Literature Pertaining to the Use of Mapping conceptping Techniques and Technologies for Education and Performance Support: The Institute for Human and Machine Cognition.

Novak, J. D. \& Gowin, D. B. (1984). Learning how to Learn. England: Cambridge University Press.

Saepuzaman, D. (2011). Penerapan Model Pembelajaran Inkuiri Dengan Kombinasi Eksperimen Nyata Virtual Pada Materi Rangkaian Listrik Arus Searah Untuk Meningkatkan Penguasaan Konsep dan Keterampilan Proses Sains Siswa SMA.Tesis Tidak diterbitkan. Bandung: Sekolah Pascasarjana Universitas Pendidikan Indonesia.
Stoddart, T. (2000). Mapping concept as Assessment in Science Inquiry Learning-A Report of Methodology. The International Journal of Science Education. 22(12), 1221-1246.

Zacharia, C. (2011). Blending Physical and Virtual Manipulatives: An Effort to Improve Students' Conceptual Understanding Through Science Laboratory Experimentation. Journal Science Education, 96(1), 21-47.

Zacharia, C. (2010). Implementing A Blended Combination of Physical And Virtual Laboratory Manipulatives To Enhance Students' Learning Through Experimentation In The Domain of Light and Color. Cyprus: Learning in Science Group, Educational Sciences, University of Cyprus. 